\title{
Local Wisdom of Lodok Rice Field in Meler Village, Manggarai Regency
}

\author{
Ottovianus Diliano Nery* \\ Geography Education Department \\ Universitas Pendidikan Indonesia \\ Bandung, Indonesia \\ *ottovianusdilianonery@upi.edu
}

\author{
Darsiharjo, Epon Ningrum \\ Universitas Pendidikan Indonesia \\ Bandung, Indonesia
}

\begin{abstract}
Lodok Rice Field from Manggarai, Province of East Nusa Tenggara is one of cultural rice field in Indonesia. This rice field has pattern look like spider web. The research was conducted to find out local wisdom of Lodok rice field and how to use it in geography learning. Descriptive method with a qualitative approach is used in this research. Observations, indepth interviews and literature study were carried out to collect data. The results showed that Lodok rice fields in Meler Village were the result of community interaction with the environment which was sourced from local knowledge. The Meler community has local knowledge in selecting land locations for agriculture, the formation of Lodok rice fields, the system of dividing rice fields, managing rice fields, and preserving the forest as a source of water. Overall, the local wisdom of the Meler village community which is poured into Lodok's rice fields contains social values and environmental conservation values. Research on local wisdom of Lodok Rice Fields gives that description of Lodok rice fields contains local wisdom values that can be used as a resource of learning geography. The outdoor study method is chosen and recommended in utilizing local wisdom Lodok Rice Fields as learning resources for geography lessons at Senior High School Manggarai Regency.
\end{abstract}

\section{Keywords—local wisdom, lodok rice field, learning resources}

\section{INTRODUCTION}

Local wisdom is interpreted as a system in the order of social, political, cultural, economic and environmental life in local communities [1]. A strong distinctive character in local wisdom is dynamic, continuous, and tied to the community. Local wisdom contains a view or rules in the form of activities carried out by the community so that people have a more foothold in determining an action or meeting their needs in life. The appearance of cultural tourism is the identity of a region [2]. Cultural identity is something that is artificial, something that is formed by a representation and it is not something that is formed naturally. Physical appearance Lodok Rice Field not just formed, but shaped by the local wisdom of the community in responding to their environment and the results of these actions are characteristic of a place or area.

Lodok Rice Field from Meler Village, Ruteng District, Manggarai Regency, East Nusa Tenggara Province is one of cultural rice field in Indonesia. This rice field has pattern look like spider web. Therefore, this rice field also known as spider web rice field. It needs to know that Lodok Rice Fields is different from rice fields in general, so the existence of Lodok Rice Fields needs to be known and try to be preserved to remember Lodok Rice Fields not just formed, but are formed based on philosophical values.

One of the efforts to study and preserve local culture is through education in schools [3]. Schools can help to develop local wisdom. Law of the Republic of Indonesia number 20 of 2003 concerning the national education system in article 50 number 5 which states that district or city governments are obliged to manage education units based on local excellence [4]. Geography subjects in schools are one of the subjects that can learn about local excellence in an area. Geography is a science that is more focused on the interaction between humans and the environment in which they live $[5,6]$. Studying culture in geography emphasizes humans and their environment, which means how space and place are formed by beliefs and values held by people who inhabit a certain place. Therefore, good geography learning is learning that integrates local culture. One of the $21 \mathrm{st}$ century capabilities published in the World Economic Forum is strengthening knowledge about culture. Strengthening knowledge about culture as one of the objectives of learning geography.

Lodok Rice Field in geography learning is categorized as an environmental learning resources [7,8]. Environmental learning resources are divided into 3 parts, namely the social environment, physical environment, and cultural environment. The purpose of learning resources is to facilitate students' understanding of the material being taught. Based on the description above, the purpose of this study is to identify local wisdom of Lodok Rice Fields and utilization in geography learning at Senior High Schools in Manggarai Regency.

\section{RESEARCH METHODS}

This research design is descriptive quantitative. This research describes the local wisdom of Lodok rice fields and an outdoor study as a method for utilizing learning resources in geography lessons at high schools in Manggarai Regency. This 
research was conducted in Meler Village, Ruteng District, Manggarai Regency. Observation, interviews and literature study were carried out to collect data.

\section{RESUlTS AND DiscUSSION}

Lodok Rice Fields is located in Meler Village. Meler is the name of a sub-village located in Meler Village, Ruteng District, Manggarai Regency, East Nusa Tenggara Province, Indonesia. The location of Lodok rice fields can be seen in Figure 1 below.

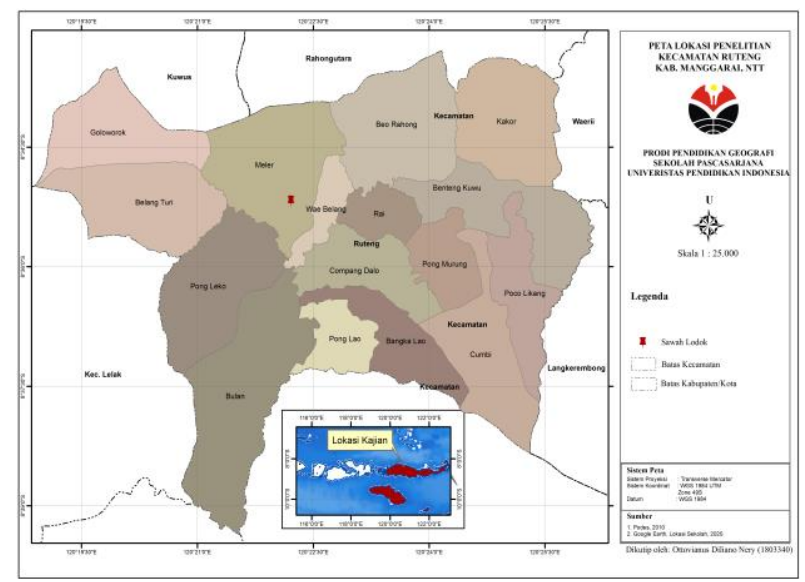

Fig. 1. Location map of Lodok rice field, Meler Village, Ruteng District, Manggarai Regency.

Geomorphologically, the Meler village, Ruteng district, has a relatively flat landscape, with a slope from the north of the village. In terms of the size of the sub-district, the soil types for the Ruteng district consist of Mediterranean and latosol soil types. Astronomically, Manggarai Regency is located between $8^{\circ} \mathrm{N}-8^{\circ} .30$ 'S and $119.30^{\circ}-12.30^{\circ}$ East. Meler Village is bordered by Rahong Utara village (North), Beo Rahong village (east), Pang Leko village (south), Bangka Turi village (West).

Lodok Rice Fields in Meler Village have a unique shape that resembles a spider web. Figure 2 is a form of the appearance of Lodok Rice Fields.

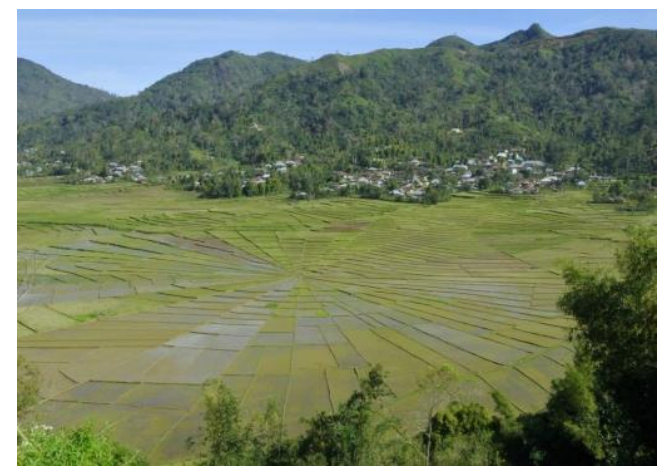

Fig. 2. The appearance of Lodok rice fields.in Meler Village, Ruteng District, Manggarai Regency.
Lodok Rice Fields in Meler village is classified as very unique since the existence of Lodok Rice Fields can only be found in Manggarai, one of which is Meler village with an area of 165 ha [8]. According to the traditional leader of Meler village, the agricultural system in Manggarai began to be developed since King Aleksander Baruk led the land of Nusa Lale Manggarai in 1931-1945. Raja Baruk strongly encourages agricultural development in Manggarai. Lodok Rice Fields in Meler village is the first rice field in Manggarai based on customs. Plantation or agricultural land in Manggarai is called Lingko (communal gardens) and the system for dividing agricultural land is called Lodok.

\section{A. Local Wisdom of Lodok Rice Field in Meler Village Formation and Division in Lodok Rice Field}

The Manggarai community in general cannot be separated from farming and gardening activities. Therefore, Manggarai people are familiar with expressions "Gendang One Lingko Peang". The phrase literally means "the drum inside and the garden outside". Drum is a gendang (musical instrument) but it can also mean a drum house, namely a traditional house, a communal house for the Manggarai people. Lingko is a communal garden. Custom home (mbaru drum) cannot be separated from garden (Lingko) which means where there are settlements or villages that are centred in traditional houses (mbaru gendang) of course have land for community cultivation called Lingko.

The people of Meler Village have local knowledge in placing locations for agricultural land. Location of the Lodok Rice Fields was chosen by the local community based on the topography of the land, the availability of forest land and water sources. Local people believe that the existence of forests as water sources can provide a long life for the community and agriculture. Therefore, the location of Sawah Lodok in Meler Village is not far from the forest area which allows the availability of water sources for agriculture (Figure 2). The shape of Lodok Rice Fields has in common with the form of a traditional house (Figure 3 and 4 ).

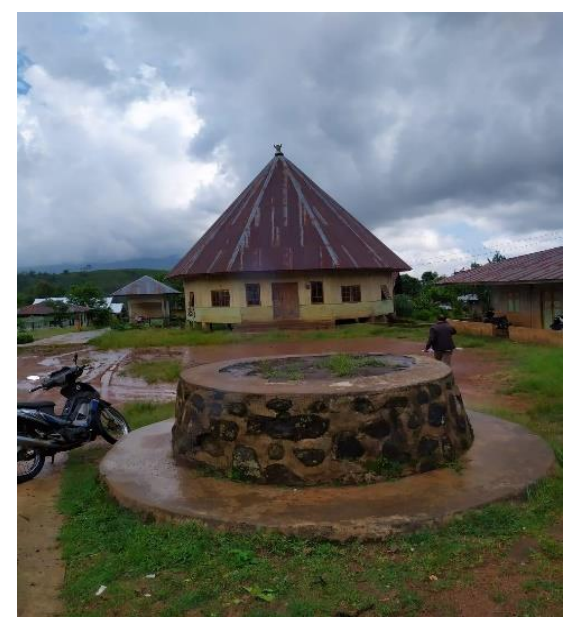

Fig. 3. Outside view of Meler village traditional house. 


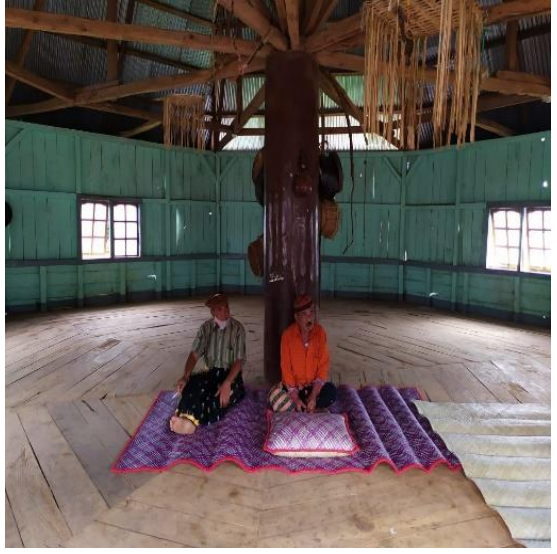

Fig. 4. Inside the traditional house of Meler village.

Traditional house form (mbaru niang) and sawah lodok (Lingko or communal gardens) which is round or circular based on the Manggarai culture namely lonto leok which means sitting in a circle. Lonto leok contains a bond of unity with the expression "Muku ca pu'u neka woleng curup and teu ca ambo neka woleng lako" Which means togetherness, kinship in one community. Therefore, Sawah Lodok which is round has the meaning of togetherness or solidarity. Local values that contain the meaning of goodness are not just values, but are implemented by the community in everyday life.

Lingko (Communal Garden) Lodok rice fields made by the ancestors aimed at dividing the land fairly and owned by all people. In clearing land for wetland farming, it is carried out on ulayat or customary land, based on an agreement or deliberation by the customary chief (Tua Golo) with the village community. The activity of forming Lodok rice fields on the land chosen by the community begins by installing tree logs at the centre point of the land. The centre point on an agricultural land called Lodok (See Figure 5). From the centre point it is then pulled out to the outer boundary of the circle according to the results of the division of land. The activity is named Tente Teno. Teno is a type of straight wood or tree that is used by the local community and based on community belief, straight wood symbolizes an honest attitude and can be trusted by others. In addition, indigenous people also carry out traditional rituals by using chickens and eggs to ask permission from the spirits who inhabit the land or land with the aim that the land used for agriculture can bring blessings to community life.

After the tente teno activity was carried out, then the distribution of rice fields to the community was carried out led by tu'a teno. Tu'a teno is the leader in the distribution of agricultural land to the community. Division of agricultural land Lodok rice fields using the system sarmoso (fingers). Customary land is divided evenly with the community. In the division of rice fields, one village community was formed into several large groups. The agricultural land that has been divided by each large group is called langang (Figure 5). In one group get a farm to divide among each member. The agricultural land that has been divided into each group member is called Moso. The shape of the cake slices in Lodok rice fields is called Moso. Meanwhile, the circular outer boundary is called Cicin (Figure 5). Following figure is a sketch of the results of land division in Lodok rice fields. The following is a sketch of the division of land in Lodok Rice Field (Sawah Lodok)

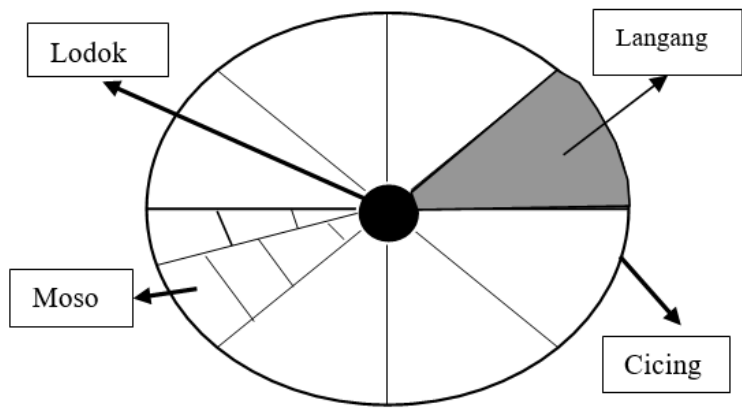

Fig. 5. Lodok rice field sketch

Figure 5 above is the result of dividing rice fields in the form of a spider web called Lodok. The people of Meler Village have 8 lodok rice fields or 8 Lingko. The land that has been divided will be managed by each member of the community and not become a legal personal property.

\section{B. Lodok Rice Field Agricultural Management}

The people of Meler village are mostly farmers in the type of agriculture, namely rice and coffee, which have been practiced from generation to generation. The management of rice plants, which until now is thick with the traditions of the Meler people, is added to its unique shape. Lodok Rice Field in Meler village it was not formed just like that but went through a long process and the management still contained local management. Processing process Lodok Rice Field starting from planting seeds in the local language, namely weri wini. Before planting the seeds, perform a ritual weri wini which is done together with the community. The purpose of this activity is so that the added seeds are avoided from plant pests and hope that they can provide abundant yields. In the management of lowland land, the community is currently using tractor-type technology and no longer uses local animal technology such as buffalo.

Use of rice seeds The people of Meler village before 1990 still used local seeds, namely woja longko, woja siwa, woja nencel, and woja bengawan. Age of production of local seeds that is 6 months and the local seedlings were planted in the mountains or forests before planting. Local seeds planted by the community without using additional fertilizers, because they are supported by the conditions of fertile soil nutrients, make rice grow without additional fertilizers. In 1990 onwards, agricultural management began to change since receiving seed and fertilizer assistance from the government, whose production age was 3-4 months earlier. Since the use of chemical fertilizers for paddy farming, soil nutrient conditions have decreased and depend on fertilizers to support rice plants. 
People choose these seeds because the production process is faster.

The water source for rice fields comes from the Meler Kuwus Mountains which are located in the north of Meler Village. Water flows from North to South Lodok Rice Field are located in the southern part of Meler Village which is not far from the forest and residential areas. The water is also used by the community for their daily needs.

In production activities or harvesting, the community performs mutual cooperation. Team work or activities of mutual assistance does not occur in rice fields alone, but in all types of agriculture, including the socio-economic activities of the community. The mutual cooperation activities carried out by the community are known as local terms, namely dodo. The word "dodo" this arises and lives in every community's heart to be able to live side by side with every community. At the end of every year the community holds a celebration for the results that nature gives. The activity in local language is called penti ceremonies. The penti ritual is performed as an expression of gratitude to God and ancestral spirits for the blessings received by the community.

\section{Preservation and Utilization of Lodok Rice Fields (Sawah Lodok)}

As an effort to maintain the existence of the lodok rice fields, local people try to maintain the balance of the function of the forest for agriculture. In addition, the inheritance system of the lodok rice fields is not determined by the customary leader, but is based on the decision of each family member. Each family member decides which child will get the rice field. For example, in one family member, the first child is given a rice field, while the second child is given a coffee or clove type of agricultural land. In the customary demand that rice fields can only be inherited, but not for sale. In Manggarai culture, a boy is the person who has the right to inherit from his parents.

Local people do not only focus on agricultural land, but also care about forests as a source of water to meet their needs and agriculture. The convincing knowledge of the local community that without the forest there is no water, without water there is no life. So that people interpret water, namely "Wae bate teku" and forest i.e. "Puar bate mose". The community applies several local wisdoms to protect forests and springs. The tribal chief forbids local people from carrying out development activities at the location of the spring, it was prohibited to catch eels because the people believed that these animals were considered to be ancestors who guarded, protected the wiko plants that could only live in the springs which became the belief of the people that the wiko plant was a sign in the function of the water container, and each spring must be maintained. Apart from the prohibition, the tribal and community leaders performed ritual activities in the springs and these activities were called Barong wae. This activity is carried out at the spring where the community needs it.

Likewise, with forests, tribal chiefs prohibit illegal logging, but if forest trees are used for housing needs, the people who need it, please notify the tribal or customary leaders. Indigenous peoples limit the expansion of land for agriculture or dry land plantations which aim to maintain forest functions and provide a balance between community needs and agricultural needs. Every community who violates the rules will be given a penalty in the form of a fine determined by the chief of the tribe according to the violation committed. Apart from the prohibition regulations, local people also carry out ritual activities. The ritual activities carried out by the village community are ceremonial activities penti. The penti ritual is carried out as a thanksgiving to God (mori jari dedek) and the spirits of the ancestors for the blessings received by the community from the natural surroundings.

Customary leader (golo old), chair in land management (old teno), and society together strives to maintain and preserve existence sawah lodok as a form of identity of the Manggarai community. The agricultural land given by the community from the results of the distribution is communal land, therefore the tribal leaders or traditional leaders prohibit sawah lodok from being sold and converted into development. However, the prohibition issued by the tribal leader is not in the form of punishment if it violates. Chieftain (Tua Adat) and head of land administration (Tua Teno) ensure that the community will not sell or change functions sawah lodok. In the land inheritance system sawah lodok in one family is done based on the decisions of the family itself, the most important is the land of sawah lodok is kept in existence.

Lodok Rice Field is used by the community not only to meet food needs, but also for tourism activities. Currently, the community and local government have made Lodok Rice Field as cultural tourism objects in Manggarai Regency besides Wae Rebo Village. According to the local community, the existence of Lodok Rice Field as a tourist spot has greatly helped them to increase their income. Thus, the community's economy does not only depend on agriculture, but is assisted by the existence of lodok rice fields as a tourist attraction.

In 2019-2020, the people of Meler village experienced a decrease in the quality of the water discharge for rice fields. The decreasing intensity of rainfall makes people lack water during the dry season. The water source produced from the forest in Meler village is not sufficient to meet the needs of rice fields, especially during the dry season. Hearing this problem, the Manggarai district government tried to solve the problem. Currently, the local government is still planning and has not been able to explain to the public about the planning that will be carried out by the local government.

\section{Settlement Pattern}

The settlement pattern of rural communities cannot be separated from the history of the formation of the village. The choice of a place to live by the Meler village community depends on soil fertility, availability of water sources, availability of forest land and topography which were the targets of local communities at that time. The settlement pattern of Meler village communities was initially concentrated, depending on the existence of a water source to 
easily meet daily needs. As time goes by, currently the settlement pattern of the Meler village community depends on the village lane or road.

The geomorphology of the Meler village area has a relatively flat landscape with a sloping direction to the north as well as being the centre of the forest in Meler village, the name of the forest is a Kuwus Meler forest, this forest extends from Meler village to Kuwus sub-district, West Manggarai Regency.

The flat land in Meler village is used by the community for settlements and Lodok Rice Field farming, while the sloping land to the north of Meler village has forest as the main source of water for local community needs. In general, soil types for the Ruteng sub-district consist of Mediterranean and Latosol soil types. The morphological and soil conditions in the village of Meler, Ruteng sub-district, lead the community to plant types such as coffee, cassava, vegetables and rice as the main sources for the needs of the village community.

\section{E. Utilization of Local Wisdom from Sawah Lodok in Geography Lessons}

Lodok Rice Field is the result of community interaction with the environment. In geography learning, local wisdom of Lodok rice field is a type of learning resource for the environment [7]. Environmental learning resources are divided into 3 parts, namely the social environment, physical environment, and cultural environment. This learning resource can be used to discuss material on "environmental use and preservation".

Environmental learning resources that are used for classroom learning are not always effective and certainly require learning resources such as tools or technology and additional media to support the implementation of the use of environmental learning resources. Learning outside of school allows learning to be more effective, because it interacts directly with the environment [9]. Direct observation gives the most complete and meaningful impression of information and ideas. Learning activities by taking students out of the classroom to interact directly with the environment by using outdoor study learning (field study), which is one of the learning methods.

Outdoor learning is one of the learning techniques that emphasizes a person's experience obtained through direct action / activities in the field. In outdoor study learning (field study) using environmental media [10,11]. Environment plays a very important role in the growth and development of children, because children will learn to understand something from the environment [12,13]. There are six advantages to outdoor study, namely: 1) Increasing the learning capacity of students; 2) Revealing facts and obtaining data in the field; 3) Encourage student learning motivation, 4) Develop socialphysical abilities, 5) Make student learning meaningful, and 6) Suitable methods are applied to Geography subjects. Apart from the advantages, there are also disadvantages to the use of outdoor studies. One of the shortcomings of outdoor study learning is that the teacher will have difficulty arranging or managing learning when in the field and it requires time and travel costs if it is far from the object location [14,15]. Learning activities outside the classroom are very possible, especially for school locations that are close to the environment or objects that are used as learning resources.

SMA Budi Dharma Cancar, Ruteng sub-district, is a school close to the location sawah lodok, which makes it possible to implement outdoor study learning, without the need to spend a lot of money and time. So far, geography learning at Budi Dharma High School Cancar is still teacher centred. Lack of learning resources such as books, tools / media and the internet, makes teacher learning still dominate with the lecture, question and answer method and tends to be in the form of knowledge transformation from teacher to student. Lack of learning resources for students also makes student note-taking activities very high in the learning process, because the only source for students to learn other than teachers is what they have recorded in class or school.

The proximity of Budi Dharma Cancar High School's location to the object reduces one of the obstacles in outdoor study learning. Outdoor study or field study is conducted if the field observation location is relatively close to the school location. This does not indicate that high schools in Manggarai Regency which are far from the object do not allow to use outdoor studies. It all depends on the teacher's strategy in utilizing Lodok rice fields. The availability of facilities such as complete learning resources, tools / media, and the internet makes learning easier without having to do field observations. Therefore, secondary data on Lodok rice fields that are available online and offline are needed by schools that are far from the location of the object.

To achieve the implementation of outdoor study learning, teachers or educators are expected to carry out careful planning related to the use and implementation of outdoor studies [10]. In carrying out learning, the following steps are required: 1) Formulating objectives; 2) make a work plan; 3) make rules during the learning process; 4) arrange assignments that must be done by students while in the field;5) Dialogue; and 6) Follow-up, namely making reports as a result of field learning. This relates to the stages in learning, namely preparation, implementation, and follow-up. The concept of environmental learning resources is to change learning activities in the classroom (indoor) to outside the classroom (outdoor) by utilizing objects in the environment then students make direct observations. Outdoor learning activities lead students to be oriented towards problems around real life, and there is a process of student activity and creativity in understanding the problems around them.

Careful planning of outdoor learning can give good results, such as being able to overcome learning boredom, providing motivation, understanding, and experience [16]. Learning outdoor study makes students more familiar with the environment. 


\section{CONCLUSION}

Lodok rice field in Meler Village, Ruteng District, Manggarai Regency is evidence of the local knowledge of the community in managing their environment. Sawah Lodok (Lodok rice field) which was made by the ancestors aims to divide the land fairly and it is owned by everyone to meet their needs. The land used is communal land. The existence of Lodok rice fields has become the cultural identity of the Manggarai people, because it was formed based on local cultural values. Local wisdom of sawah lodok is related to social life and utilization of natural resources.

Using the local wisdom of Lodok rice fields in learning is one of the efforts to preserve local culture. The local wisdom of Lodok rice fields is used to complement the needs of geography material in Senior High Schools. Outdoor study (field study) as a method to utilize local wisdom of Lodok rice field in geography learning at SMA Manggarai, especially SMA Budi Dharma Cancar, because of its proximity to the object. Budi Dharma Cancar High School is a school that is close to the location of the object, making it possible to implement outdoor study learning. The choice of outdoor study is a solution to overcome the lack of learning resources such as books, scientific papers, media / tools, and the internet. The benefits of field studies can provide students with experiences gained through field activities.

\section{REFERENCES}

[1] W. Wagiran, "Pengembangan Karakter Berbasis Kearifan Lokal Hamemayu Hayuning Bawana (Identifikasi Nilai-Nilai Karakter Berbasis Budaya)," Jurnal Pendidikan Karakter, vol. 3, 2012.

[2] C. Barker, Cultural Studies. Yogyakarta: Kreasi Wacana, 2000.
[3] M. Ferrari and G. Potworowski, Teaching for Wisdom: Cross-Cultural Perspectives on Fostering Wisdom. Netherland: Springer, (p. 37-57), 2008

[4] Undang-Undang Republik Indonesia Nomor 20 Tahun 2003 Tentang Sistem Pendidikan Nasional, Cet.1. Jakarta: Bp Panca Usaha, 2003.

[5] J.J. Hobbs, World Regional Geography. USA: Brooks/Cole, 2009.

[6] J. Giles and Tim Middleton, Studying Culture; A Practical Introduction. Oxford: Blackwell Publishers, 1999.

[7] E. Ningrum and A. Yani, "A Design of Environmental-Based Learning to Instill Land Ethics in the Learners," American Journal of Applied Sciences, vol. 13, no. 12, pp. 1461-1469, 2016.

[8] F. Sumardi and P. Sukardja, "Makna Dan Fungsi Sawah Lodok D Kampung Meler Desa Meler Kecamatan Ruteng Kabupaten Manggarai Nusa Tenggara Timur,” Jurnal Humanis, vol. 18, no. 1, pp. 10-15, 2017.

[9] A. Arsyad, Media Pembelajaran. Jakarta: PT Raja Grafindo Persada, 1997

[10] S. Sumarmi, Model-model Pembelajaran Geografi. Malang: Aditya Media Publising, 2012.

[11] H. Husanah, Pembelajaran Luar Kelas Outdoor Learning. Jakarta: Prestasi Pustaka Karya, 2019.

[12] N. Sudjana and R. Rivai, Media Pengajaran. Bandung: Sinar Baru Algesindo, 2010.

[13] A.E. Sejati, S. Sumarmi and N. Ruja, "Pengaruh Metode Pembelajaran Outdoor Study Terhadap Kemampuan Menulis Karya Ilmiah Geografi SMA," Jurnal Pendidikan: Teori, Penelitian, dan Pengembangan, vol. 1, no. 2, pp. 80-86, 2016

[14] H. Harini, "Pengaruh Pembelajaran Tugas Kelompok Berdasarkan Survei Lapangan (Outdoor Study) terhadap Kemampuan Menulis Karya Ilmiah dan Hasil Belajar Siswa," Jurnal Penelitian Pendidikan LemlitUM, vol. 22, no. 1, pp. 12-21, 2012.

[15] A.E. Sejati, L.O. Amaluddin, D. Hidayati, S.K. Sejati, S. Sumarmi and N. Ruja, "The effect of outdoor study on the geography scientific paper writing ability to construct student character in senior high school," In 5th SEA-DR (South East Asia Development Research) International Conference 2017 (SEADRIC 2017). Atlantis Press.

[16] K. Paisley, N. Furman, J. Sibthorp and J. Gookin, "Student learning in outdoor education: a case study from the national outdoor leadership school," Journal of Experimental Education, vol. 30, pp. 201-222, 2008. 